\title{
AUGMENTATION OF SPECIFIC AND NON-SPECIFIC PROTECTION IN OREOCHROMIS NILOTICUS TREATED WITH SOME PREBIOTICS AND / OR BACTERIN.
}

\author{
Gado, M. S. * and Azza A. Kattawi.** \\ Fac. of Vet. Med., Kafr El-Sheikh, Tanta Univ. Poultry and Fish Dept. * \\ ** Physiology and Biochemistry Dept.
}

\begin{abstract}
We experimentally infected Oreochromis niloticus (O.niloticus) fish with Hafnia alvei (H.alvei), the causative agent of fish haemorrhagic septicemia in order to compare the immunological responses to different treatments with glucan,alginate and/or in combination with H.alvei bacterin.Elevations in the non-specific defence mechanisms were noted after O.niloticus were bathed in glucan,alginate, and bacterin solutions or in solutions containing the glucan or alginate combined with a bacterin.Blood samples were collected in several times showed an elevation in neutrophil activity through the ability of the cells to stick to glass and produce oxidative radicals where detected by the nitroblue tetrazolium (NBT) assay which increased after treatments in all groups within 48 hours. The numbers of circulatory glass-adherent cells from fish given the alginate, glucan and / or bacterin by bath was significantly higher than at the begining of the experiments or the control levels. Elevated phagocytosis, assessed by increased uptake of glutaraldhyde-treated sheep red blood cells, also confirmed these kinetics. It is obvious that fish given alginate and glucan in combination with bacterin, the kinetics of the non-specific and specific immune responses were significantly remarkable. The most promising group of immunostimulant are the alginate and the glucan and they could play an important role as immunomodulators in fish farming and in the prevention of diseases in fish cultures. This paper will present data on such effects with reference mainly to prebiotics and how can induce a systemic effect.
\end{abstract}




\section{INTRODUCTION}

Prebiotic agents are nondigestible food ingredients that beneficially affect the host by selectively stimulating the growth and / or activity of one or a limited number of gut bacteria that can improve the host health (Gibson, 1999). Moreover, prebiotics modulate enteric and systemic immune functions (Buddington et al., 2002).

Immune-stimulants are mostly chemical compounds that activate white blood cells(leukocytes)and hence may render animals more resistant to infections by viruses, bacteria, fungi and parasites (Raa, 2000).

Furthermore, the use of immunostimulants for the prevention of fish diseases progresses were as several preparations and protocols are becoming more promising (Anderson, 1992 and Raa et al., 1992). Common carp given glucan preparations by injection, by bath or in feed are more resistant to infections with Edwardsiella tarda and Aeromonas hydrophila through the activation of the non-specific immune system (Yano et al., 1989 and 1991). Moreover, glucan supplement enhanced the protection of Atlantic salmon against infections with Yersinia ruckeri, Vibrio anguillarum and Aeromonas salmonicida (Robertsen et al., 1990).

On the other hand, Fujiki et al. (1993) found that sodium alginates have a similar immunostimulating activity. Catfish injected with glucan showed increase in the non-specific defence parameters of phagocytic cell activity, the specific immune response and protection against the disease (Chen and Ainsworth, 1992). The non-specific defence mechanisms of rainbow trout include neutrophil activation, the production of peroxidase, oxidative radicals and investigation of other inflammatory factors which are similarly recognized to exist in mammalian systems (Finn and Nielson, 1971; Ellis, 1977; Ainsworth et al.,1991; Anderson et al., 1992). The neutrophils in rainbow trout showed at least three characteristics including diapedesis or active migration from the circulatory system toward an injury site, a phenomenon that can be assayed in vitro by the cells, ability to adhere to glass; oxidative radical production directed at the destruction of invaders, which can be detected by chemiluminescence or nitroblue tetrazolium(NBT)staining; and phagocytosis or the engulfment of particles for clearance. 
Hafnia alvei (H.alvei) is a wide spread Gram-negative bacterium, classified as a causative agent of intestinal disorders, which is found in fish (Sanders and Fryer, 1988) and has been reported to cause haemorrhagic septicemia and mortalities in Rainbow trout (Gelev et al., 1990), Cherry salmon (Tashima et al., 1992) and Oreochromis niloticus and Clarias gariepinus (Gado and Abd El-Aziz, 2003) .

The present work was carried out to study the efficacy of glucan and alginate on the immune response of O.niloticus fish challenged with H.alvei and demonstrated the elevations in the non-specific defence mechanisms.

\section{MATERIALS AND METHODS}

(1) Fish:Nile tilapia(Oreochromis niloticus) fish,weighing 50 \pm 5 grames, collected from a commercial fish farm in kafr El-Sheikh Governorate and acclimatized for 2 week at 22-23 $\dot{C}$ in 60-L aquaria with recirculating and filtered well water-During acclimatization and experiments. Fish were fed on a commercial ration adlibtum and determined to be free of bacterial pathogens specially H.alvei.

(2) Prebiotics: The glucan and alginates were supplied from Sigma Chemical Co., St Louis, MO, USA. The prebiotics were mixed with the dechlorinated-water when used for the bath exposures.

(3) Bacterin: The H.alvei bacterin was an $\mathrm{O}$-antigen preparation. The strain originated from $\boldsymbol{O}$. niloticus fish and was obtained from $\boldsymbol{D r}$. Gado, Dept. of Poultry and Fish, Fac. of Vet. Med., Tanta Univ. The bacterin was made from 48 hours growth harvested of $20 \mathrm{~L}$ trypticase soy broth from the fermenter and processed to $\mathrm{O}$-antigen preparations by an alcohol-acetone method (Edwards and Ewing, 1972).

(4) Bacterium: A well identified, virulent strain of H.alvei was devoted by Dr. Gado, Dept. of Poultry and Fish,Fac.of Vet.Med.,Tanta Univ., Egypt. The virulence of the bacterium was enhanced by passing three times through $\boldsymbol{O}$. niloticus fish. The isolate was then stored on trypticase soy agar slants at $4^{\circ} \mathrm{C}$ under mineral oil.

An inoculum was prepared by growing bacteria on heant infusion agar at $37^{\circ} \mathrm{C}$ for 48 hours (Gelev et al., 1990), and suspending in a sterile saline at a concentration $0.1 \mathrm{ml} \mathrm{x} 10^{9}$ forming units ml-1 (Rodriguez et al., 1998). 
(5) Challenge test and sampling protocols: The fish stocks used in this study were divided into 7 groups $\left(G_{1}-G_{7}\right), 20$ fish of each except $G_{6}$ and $\mathrm{G}_{7}, 10$ fish of each. Fish of $\mathrm{G}_{1}-\mathrm{G}_{6}$ were injected intraperitoneally with $0.1 \mathrm{ml}$ of bacterial suspension containing $10^{9}$ forming units $\mathrm{ml}^{-1}$ and $\mathrm{G}_{7}$ kept as a control were injected with the same volume of sterile phosphate buffer saline (PBS) and maintained in the same conditions. Fish of $G_{1}$ and $G_{2}$ were placed in glucan and alginate baths in the concentration of $100 \mu \mathrm{g} / \mathrm{ml}$ for 30 minutes, respectively, which done 6 days prior to intraperitoneal challenge with H.alvei. (Jeney and Anderson, 1993 and Fujiki et al., 2000).

Fishes of $\mathrm{G}_{3}$ were placed in a $100 \mu \mathrm{g} / \mathrm{ml}$ H.alvei bacterin bath for 2 minutes, 5 weeks prior to the intraperitoneal challenge with H.alvei (Jeney and Anderson, 1993).

Fish of $\mathrm{G}_{4}$ and $\mathrm{G}_{5}$ were placed in glucan and alginate baths in the cancentration of $100 \mu \mathrm{g} / \mathrm{ml}$ for 30 minutes, respectively, then placed in $100 \mu \mathrm{g} / \mathrm{ml} \mathrm{H}$.alvei bacterin bath for 2 minutes, 5 weeks prior to the intraperitoneal challenge with H.alvei (Jeney and Anderson, 1993).

Fish of $\mathrm{G}_{6}$ were challenged with $\boldsymbol{H}$.alvei and were kept without any treatment .

Mortalities were recorded daily untill11days postchallenge where the injected organism was recovered in pure culture from the internal organs(Rodriguez et al.,1998). Bacterial counts in the blood and spleen were determined by plate counts on tryptose soya agar (Unipath, Basingstock, England). Blood samples were taken at different times immediately before treatment and 12, 24, 48, 72, 96 and 240 hours after challenge for measuring the specific and non-specific defence mechanisms and fish were bled by caudal puncture. Individual fish were sampled only once to avoid the influence on the assays due to multiple bleeding and handling stress on the fish and investigated for the following:

(A) Antibody titers: Specific antibody titers in the collected serum samples to H.alvei were quantitated using bacterial agglutination test. For agglutination, formalin-killed bacterial cells were washed twice with sterile saline solution and prepared to a concentration of $3 \mathrm{mg}$ wet-weight / $\mathrm{ml}$ saline (Baba et al., 1988). 
(B) Separation of leukocytes from blood: Blood from each sample was used for density-gradient centrifugation leukocyte isolation assays. Two milliliters of Mono-Poly Resolving Medium (M-PRM) FicollHypaque (1.114 g/ml; Flow Laboratories, Inc., McLean, VA), a nonionic synthetic sucrose polymer, were dispensed with $0.75 \mathrm{ml}$ of Bacto Hemagglutination Buffer,PH 7.3(Difco Laboratories, Detroit, MI). The buffered M-PRM solutions were vortexed briefly for complete mixing,then $1 \mathrm{ml}$ of the blood sample was carefully layered on top of the medium. The sample preparations were centrifuged at $500 \mathrm{~g}$ for 10 minutes at $4^{\circ} \mathrm{C}$. After centrifugation, separated leukocytes were gently removed and dispensed into siliconized microcentrifuge tubes . PBS was added until the leukocytes were once again suspended in $1 \mathrm{ml}$ of solution establishing comparable cell number/ volume ratios with the original blood sample (Jeney and Anderson, 1993).

(C) Leukocyte count: Total leukocyte counts were calculated using hemocytometer. Leukocytes were fixed and stained by using the following solution: $0.1 \mathrm{~g}$ crystal violet and $1.92 \mathrm{~g}$ citric acid in 100 $\mathrm{ml}$ distilled water. Fifty microtiter of the cell suspension was added to $1 \mathrm{ml}$ of the solution and the cells were counted.

Blood smears stained with Wright's stain were prepared to determine the percent of monocytes and neutrophils. Two hundred leukocytes were differentiated morphologically. Monocyte and neutrophil numbers were calculated from total leukocyte numbers (Jeney and Anderson, 1993).

(D) Oxidative radical production (NBT assays): A volume of $0.1 \mathrm{ml}$ sample of the separated leukocyte suspension and an equal volume of nitroblue tetrazolium (NBT) solution $(0.2 \%$ in PBS) were mixed together and a sample placed on the hemocytometer (Bright-Line, American Optical Co.,Buffalo,NY).NBT-positive cells were counted 30 minutes later.Two samples from each fish were set up(Jeney and Anderson, 1993).

(E) Glass-adherent NBT-positive cells: The solution of NBT was used to determine the levels of oxidative radical production by glassadherent neutrophils.Procedures followed were similar to Anderson et al. (1992), which done by placing a single drop of blood $(20 \mu \mathrm{l})$ 
on a glass microscope slide and setting it to incubate in a humid chamber for 20 minutes to allow the cells to adhere, after washing with PBS. The NBT stain was allowed to cover the cells for 30 minutes. After washing with distilled water, blood smears were air dried, fixed in methanol and stained with safranin. Leukocytes (500) were counted for the determination of percentage of glass-adherent cells staining positive for NBT (Jeney and Anderson, 1993).

(F) Phagocytosis assays: Phagocytosis assays were performed according to the method of Sövényi and Kusuda (1987). Leukocyte $(0.1 \mathrm{ml})$ suspensions were placed in microtitre wells and incubated with glut-araldehyde-fixed SRBC ( $1 \mu 1$ of an $8.0 \%$ suspension) for 30 minutes on a shaker at $15^{\circ} \mathrm{C}$, before a drop from each sample placed on a slide and a smear was made. After drying, the smear was stained with Wright's stain. The results of the phagocytosis assays are presented as a direct reading (percentage of cells with engulfed SRBC).

(6) Statistical analysis: The mean and standard error of the mean (s. e. m.) was calculated for each treatment. Validity was determined by the Student's $t$-test.

\section{RESULTS}

\section{(A) Effects of prebiotics and/or bacterin on the survival of $O$.niloticus fish challenged with H.alvei :}

A summary of the experiments showing enhancement of disease resistance in the O.niloticus fish treared with glucan , sodium alginates and / or bacterin is presented in Table (1). In seven different challenge experiments with H.alvei , the causal agent of septicemia, water baths of prebiotics and/or bacterin in $\boldsymbol{O}$.niloticus resulted in a relative percentage protection (survival \%) 65-100\% in groups $1-5$ versus $10 \%$ survival in group number 6 (challenged untreated control group).

\section{(B) The immune response of $O$.niloticus to different treatment:}

The immune response of O.niloticus fish against H.alvei bacterin was given in Table (2). In this experiments, the antibody response in fish bathed with glucan, alginate, and/or bacterin were demonestrated at high 
titers in group No.5 and remained relatively as such during the experimental peroid.These situation of significantly antibody titers were higher than initial values(control) of all treated groups leds to the increased resistance observed in glucan and alginate-treated fish may be due to enhanced specific resistance because the successful challenge may have induced specific immunity towards $\boldsymbol{H}$.alvei . If that are these cases, the protective effect of glucan and alginate are likely to be an adjuvants effect.

\section{(C) Bacterial counts in blood and spleen post infection:}

Bacterial counts in blood of all groups on supplemented prebiotics and / or bacterin were lower than in controls during the all peroid of the experiments (table 3). Lower numbers of bacteria were detected in spleen samples from the all treated groups than from controls at 6 and 12 hours post infection revealed prebiotics were enhancing the phagocytic function and elimination of bacteria.

\section{(D) Changes in number and functions of leukocytes:}

Changes in numbers and functions of circulatory leukocytes were observed due to the effects of baths treatments with glucan, or alginate or bacterin adiministered alone, or when the immunostimulant was given in combination with the bacterin (table 4).

The total number of circulating leukocytes was found to be reduced at 12 hour sample but increased in the 24 hour sample for each treatment. Fish treated with either the glucan combined with bacterin or with the alginate combined with bacterin showed significantly higher numbers of circulatory leukocytes through the remaining sample times.

\section{(E) Neutrophil numbers:}

Total numbers of neutrophils rose most significantly in fish given alginate with bacterin (table 5). The tendency of increasing numbers of neutrophils followed the tendency of total number of circulatory NBTpositive cells. The counts showed that in the later samples taken at 96 and 240 hours from fish treatment, the activity was still high. The combination of the bacterin and prebiotics seemed to have a greater effect on the numbers when compared to prebiotics alone. 


\section{(F) Monocyte numbers:}

Total numbers of monocytes showed a reduction at 12 hour samples in all treated groups (table 6). By 24 hours, the monocyte numbers were beginning to increase than normal levels. The most remarkable findings was the increase in numbers of monocytes in fish administered bacterin with glucan or alginate.

\section{(G) NBT-positive cell numbers:}

The total numbers of circulating,NBT-positive cells increased within 24 hours and in fish group treated with bacterin, the increase was constant (table 7).A peak of the numbers of active cells occurred for the fish given a combination of prebiotics and bacterin at 96 hours. The most remarkable findings, in fish group treated with a combination of sodium alginate and bacterin, the maximum of NBT - positive cells was measured at 240 hours after challenge. At the end of the experiment, the level of cells producing oxidative radicals remained significantly higher compared to the starting point in all treated groups.

\section{(H) Percentage of glass - adherent cells positive for NBT:}

Fish group treated with bacterin alone showed slight reduction in numbers of glass-adherent,NBT-positive leukocytes within 12 to 24 hours. Then in all treated groups, a rapid rise in numbers occurred between 24 and 48 hours post challenge. The increasing percentage of glass-adherent cells in bathed fish with prebiotics was delayed and the highest numbers were measured at 72 hour.After 72 hour, a tendency toward a constant decrease in number of these cells was noted in all experimental groups. The fish groups given the combination did not have levels more than those administered the prebiotics alone.

\section{(I) Phagocytosis ratio:}

A significant reduction in percentage of phagocytic cells was noted at the 12 hour sample in all experimental groups. Begining at 24 hour, the phagocytic activity constantly increased and a maximum was measured by the 72 hour sample in all treated groups (table 8).

The phagocytosis ratio remained at significantly higher levels compared to the controls and the levels measured at the begining of the experiment. 


\section{DISCUSSION}

One of the most promising areas for the development of functional foods lies in modification of the activity of the gastrointestinal tract by the use of prebiotics.

This study has demonstrated that soduim alginate and glucan as prebiotics enhanced the resistance of O.niloticus fish to H.alvei infection. The disease resistance occurred within a few days, earlier than would be expected if the specific immune response was involved.Therefore, it seems likely that the glucan and alginates stimulated the non-specific immune system, presumably the reticuloendothelial system (Fujiki et al., 2000).

Moreover, the bacterin prepared from H.alvei and used in this experiments revealed that it was antigenic in nature and able to stimulate the immune system of $\boldsymbol{O}$.niloticus fish to produce high levels of specific antibodies. The immune response of $\boldsymbol{O}$.niloticus against $\boldsymbol{H}$.alvei bacterin is similar to those reported by many authors in other fish species and against different microorganisms (Collins et al., 1979 ; Lamers and Parmentier,1985 ; Ruangpan et al.,1986; Badran et al.,1993; Badran, 1994; Badran and Hussein, 2000).

On the other hand, fish groups treated with a combination of prebiotics and bacterin showed highly significant differences in protection than other groups.Many authors worked in this era gave a scenario for an explaination that immune - stimulants prebiotics are used as helper substances (adjuvants) in vaccine to activate antigen presenting cells and to stimulate these cells to produce more of the signal molecules which activate the group of lymphocytes which produce specific antibodies.It is a discovery of great practical significant that glucan and alginate act as a true adjuvant which enhances antibody production, not only when administered together with the vaccine antigens, but also when administered in the feed and the vaccine antigens by bath or injection (Nicoletti et al .,1992; Raa et al., 1992; Verlhac et al., 1998). Moreover, Raa et al. (1992); Raa (1996) and Fujiki et al. (2000) were concurrent with our results and gave their final

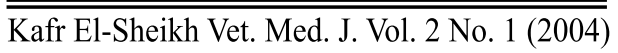


conclusion that the practical significance of this observation is that feeding of fish with glucan and alginate enhance the production of antibodies against pathogens present in the local environment and thus help to build up an effecient specific resistance against such pathogens, in addition to enhancing the non - specific cellular defence.

Measurements of bacterial counts in blood and spleen of the treated O.niloticus fish showing lowering detection than in the controls which referring that glucan and alginate were capable to enhance the phagocytic function and elemination of such bacteria. Furthermore, response to the alginate was more rapid than to the glucan, but in both cases, decreaased with continued administration. These results was coinciding with the findings of Raa et al. (1992); Ainswortth et al. (1993) and Nikl et al. (1993).

In general, the immune - stimulant are chemical compounds that activate white blood cells (leukocytes) and hence may render fish more resistant to infections by viruses, bacteria,fungi and parasites (Raa,2000).

These experiments further described and separated some of the kinetics and functions of the neutrophils and other leukocytes after the bath of the bacterin, alginate and glucan in O.niloticus fish. Kinetic patterns for the neutrophil elevations were described in catfish after physical stress with the aid of neutrophil-specific monoclonal antibody byBly et al.(1990). The authors raised questions to the source of circulatory neutrophils after physical stress, whether they arose quickly by mitogenesis, came from storage sites in the kidney and spleen, or whether they moved from locations on the margins of capillaries. In any case, the catfish neutrophil populations returned to normal 3 days after the physical stress, whereas it took more than 10 days for the $\boldsymbol{O}$.niloticus neutrophil populations to return to normal after the bath of bacterin or alginate or glucan or their combination.

The reduction and increases in neutrophil and monocyte numbers in circulation followed slightly different patterns than described before in 
trout (Anderson et al., 1992) and catfish (Bly et al., 1990). There was a brief drop in neuutrophil and monocyte numbers at 12 hours after immunization, followed by a sharp rise, perhaps compensating for the earlier depletion. The rise of the neutrophil and monocyte population was greater compared to that of the total leukocyte counts. As lymphocytes constitute the major leukocyte population in the blood, this may indicate the independence of the lymphocyte and neutrophil functions during this stressful period, as previously proposed by Bly et al. (1990) and Anderson et al. (1991).

Fish,on the other hand, have not developed histologically distinct and specialised lymphoid tissues such as the Peyer's patches of warm blooded animals, and special gateways for absorption of particles,like the M-cells. However, all the cell types responsible for a local immune response are present in the intestinal wall of fish (e. g.carp and tilapia),including immunoglobulin positive lymphocytes (B-cells), immunoglobulin negative lymphocytes (T-cells), and antigen preseniting macrophages (Davina et al., 1980; Doggett and Harris, 1987; Rombout et al., 1989; 1993). Like in warm blooded animals, the gut associated immune system of fishes seems to function in the absorption of macro-molecules from the intestine and in the production of antibodies in response to antigens (Hart et al., 1988). In other words, immune cells in the gut of fish may function like mammalian M-cells in sampling macromolecules.By this assumption one may explain the fact that alginate and glucans, also when administered in the feed of fish, enhance their disease resistance, growth performance and the efficacy of bathed vaccines.

The population of glass-adherent NBT-positive cells increased rapidly after treatment within 24 and 48 hours. As time progressed, the percentage of the glass-adherent cells was reduced, while the total numbers of NBT-positive cells in blood kept rising. The latter populations may be neutrophils that have lost their glass-adherent abilities, whereas these cells still retain capacities for the production of oxidative radicals. These separate functions have not been reported for mammals, perhaps because the funcKafr El-Sheikh Vet. Med. J. Vol. 2 No. 1 (2004) 
tions at the higher temperatures of the exotherms proceed too rapidly; whereas, in cold water fish held at $12 \dot{\mathrm{C}}$, the separation could be distinguished which congruent with Anderson et al. (1991).

The use of alginate and glucan appears to be an important additional means in the prevention or the reduction of diseases in fish culture (Nikl et al.,1991; Onarheim,1992). The effectiveness of the alginate and glucan can be followed by using the non-specific defence mechanisms as indicators. The kinetic curves of the neutrophil responses, for instance, showed a doubling of activities during the period of 2 - 4 days after bath. When the bacterin is given alone, the non-specific defence mechanisms assays show highest levels between days 1 and 3 after bath, whereas the response to the alginate and glucan given either alone or with the bacterin extends that plateau. We have previously followed similar results after administration of the bacterin in fish as well as a reduction of leukocytes 6 - 24 hours after administration(Anderson et al.,1992; Galina and Anderson, 1993).

The glucans,commonly found in fungal cell walls, may stimulate the immune system of fish similarly to bacterial endotoxin s. As products from invasive and potentially disease-causing microorganisms, these substances signal alarm or risk to fish and,having previous individual or evolutionary experiences,fish may be inherently programmed to respond to the violation which congruent with Galina ana Anderson (1993).

Alginate and glucan has proved to enhance the biological activity of treated fish hemocytes and to improve growth, survival rate and feed conversion efficacy under experimental conditions which corresponding with the finding of Sung et al.(1994);Song and Hsieh(1994); Sung et al. (1996); Sung et al.(1998); Song et al. (1997); and Supamattaya (1998). To maintain an elevated level of resistance, the immune-stimulant has to be administered on a continuous basis (Raa, 2000).

From our findings, it has been shown that the immune-stimulants may act in synergy with bacterin in preventing infections in fish. There is a 
sound biological basis for such a synergy; the aggressiveness of the infectious bacterium is lowered by the anti-microbial agent while the antibacterial mechanisms of the body itself are being stimulated. It is therefore worth consideration to use immune-stimulants in combination with curative anti-microbial agents at an early phase of disease develop-ment, or prior to anticipated disease outbreak(Thompson et al.,1993 a,b).

On the other hand,O.niloticus defensive systems are not as complex as mammalian counterparts, and indeed,because the fish are comparatively short-lived, disadvantaged by a lower metabolism in colder temperatures, and positioned lower in evolutionary development (Warr and Cohen, 1991), the fishes defensive systems are based on a more prepared, immediate response, non-specific defensive mechanisms, rather than relying on the more complex specific immune systems that have developed in higher mammals (Finn and Nielson, 1971; Van Ginkel et al., 1985). The specific immune response takes longer to investigate, and involves a much more complex and interactive system(Anderson,1979). It becomes apparent that the fishes'non-specific responses are not as directed as precise actions, and indeed, are not as prolonged; however, they are functional for short periods of protection through stress and pathogen exposure. One of the greatest difficulties of working with non-specific assays in fish is the high variability of the results. In our hands the three parameters of leukocyte counts,NBT assays and phagocytosis seemed adequate, and the glucan, alginate, bacterin or the combination introductions into $\boldsymbol{O}$.niloticus elevated all of these.Chen and Ainsworth(1992), working with the catfish model, found no increase in hydrogen peroxide function upon yeast glucan stimulation. These finding are in contrast to the oxidative radical production revealed by the NBT test in the O.niloticus model. We have attempted to make the NBT assays as simple and reliable as possible in order to make them a vailable for field use; however, these same procedures may not apply to all fish species, and may have to be modified in some cases.

Furthermore, there are another explaination that alginate and glucan bind specifically to a "receptor molecule" on the surface of phagocytes Kafr El-Sheikh Vet. Med. J. Vol. 2 No. 1 (2004) 
(Engstad and Robertsen, 1994). The receptor for alginate and glucan has been retained during evolution and is found in all animal groups from invertebrates, such as shrimp, to man. This is why alginate and glucan have the same basic biological effect within the whole animal kingdom. When the receptor is engaged by alginate and glucan, the cells become more active in engulfing, killing and digesting bacteria and at the same time they secrete signal molecules (cytokines) which stimulate the formation of new white blood cells.In animals which have the specific immune mechanisms in addition to non-specific defence (fishes and higher up in evolution), the activated phagocytes produce cytokines which also activate antibody-producing white blood cells (B- and T-cells). Therefore alginate and glucan enhances also the efficacy of vaccines. Due to the very basic mode of action of alginate and glucan,products in this category (prebiotics) affect a number of different biological processes (Raa , 2000).

\section{CONCLUSION}

the general resistance in farmed fish or as adjuvants in combination with fish vaccines. The application of highest potential is as additives in the feed. Therefore, the main effort in this research is directed towards the use of alginate, glucan and/or H.alvei bacterin in fish diseases control.

The interaction of disease and stress in fish farming appears to be a fruitful area for further research, and until we gain more information, our understanding of the ecological effects of fish diseases will remain limited.

These findings call into question the value of long-term administration of immunostimulants to fish and suggest the need for caution in using high doses. Further studies are needed to explain the relation between the enhancement of protection, dose consumption and administration peroids of an immunostimulant.

\section{Acknowledgement:}

The authors gratefully aknowledge the criticism of the work by Dr. A. A. El-Gohary,Prof. of Poult. Dis., Head of Poultry and Fish Dept., Fac. of Vet. Med. (Kafr El-Sheikh), Tanta Univ. 


\section{REFERENCES}

- Ainsworth,A.J.;C. Dexiang,and P.R.Waterstrat (1991): Changes in peripheral blood leukocyte percentages and function of neutrophils in stressed channel catfish. J. Aquat. Anim. Health. 3 : 41- 47.

- Ainsworth A. J.;C. P.Mao, and C.R.Boyle (1993): Immune response enhancement in channel catfish. Ictaiurus punctatus, using B-glucan from Schizophyllum commune. In : Modulators of Fish Immune Resp-onse . Vol. 1(Ed. by J. S. Stoten and T. C. Fletcher), Pp. 67 - 81. SOS Publications, Fair Haven, NJ.

- Anderson, D. P. (1979): Cellular response in rainbow trout Salmo gairdneri Richardson to Yersinia ruckeri O-antigen monitored by passive haemolytic plaque assay test . J. Fish Dis., 2 : 169 - 178.

- Anderson,D. P.; T. Morimoto, and R.De Grooth (1991): Neutrophil, glass-adherent, nitroblue tetrazolium assay gives early indication of immunizaion effectiveness in rainbow trout. Veterinary Immunology and Immunopathology, 30 : 419 - 429.

- Anderson, D. P. (1992): Immunostimulants, adjuvants, and vaccine carriers in fish : applications to aquaculture . Annu. Rev. Fish Dis., 2 : $281-307$.

- Anderson, D. P. , and G. Jeney (1992): Immunostimulants added to injected Aeromonas salmonicida bacterin enhance the defence mecha-nisms and protection in rainbow trout (Oncorhynchus mykiss). Vet. Immunol. Immunopathol., 34 : 379 - 389 .

- Anderson,D. P.;T. Moritomo, and R. De Grooth (1992): Neutrophil, glass-adherent, nitroblue tetrazolium assay gives early indication of immunizaion effectiveness in rainbow trout. Veterinary Immunology and Immunopathology, $30: 419$ - 429.

- Baba, T.; J. Imamura, and K. Izawa (1988): Immune protection in carp, Cyprinus carpio L., after immunization with Aeromonas hydrop-hila crude lipopolysaccharide. J. Fish Dis., 11 : 237 - 244.

- Badran, A. F. ; I. A. Eissa, and M. E. Eisa (1993) : Studies on the role of lymphoid organs in antibody production and protection 
of Nile Tilapia against infection with Aeromonas hydrophila . Zag . Vet J., 21: 153 - 160.

- Badran, A. F.(1994): Some studies on the effect of oxytetracycline on the immune response and susceptability of Nile Tilapia to pseudomonas fluorescense infection. J. Egypt Vet. Med. Ass, (54), $3: 191-197$.

- Badran,A.F., and M. M. Hussein (2000): The role of domestic waste water bacterial pollution on the histamine production in some fishes and immune response to catfish (Clarias Lazera). Assiut Vet. Med. J. Vol. 43 No. (86) : 228 - 238.

- Bly, J. E.; N. W. Miller, and L. W. Clem (1990): A monoclonal antibody specific for neutrophils in normal and stressed channel catfish. Dev. Comp. Immunol., 14 : 211 - 221.

- Buddington, K. K.; J. B. Donahoo, and R. K. Buddingtion (2002): Dietary oligofructose and inulin protect mice from enteric and systemic pathogens and tumor inducers. J. Nutr., (132) : 472 - 477.

- Chen, D., and A. J. Ainsworth (1992): Glucan administration poten-tiates immune defence mechanisms of channel catfish, Ictalurus punc-tatus Rafinesque. J. Fish Dis., 15 : 295 - 304.

- Collins, M. T.; D. L. Dawe, and J. B. Gratzek (1979): Immune resp-onse of channel catfish under different environmental conditions. J. of Am. Vet. Med. Ass., 169 (a) : 991- 994.

- Davina, J. H. M.; G. T. Rijkers; J. W. M. Rombout; L. P. M. Timmermans, and W. B. van Muiswinkel (1980): Lymphoid and nonlymphoid cells in the intestine of cyprinid fish, Pp. 129 - 140. In : Development and differentiation of vertebrate lymphocytes, (J. D. Horton, ed.). Elsevier / North-Holland Biomedical Press, Amsterdam.

- Doggett,T.A., and J.E.Harris (1987): The ontogeny of gutassociated lymphoid tissue in Orechromis mossambicus. J. Fish Biol, 31, Suppl. A : 23 - 27. 
- Edwards, P. R., and W. H. Ewing (1972): Identification of Enterob-acteriaceae, $3^{\text {rd }}$ ed. Burgess Publishing Company, Minneapolis, Minn-esota.

- Ellis, A. E., (1977): The leukocytes of fish : a review. J. Fish Biol.,11: 453 - 491.

- Engstad, R. E., and B. Robertsen (1994) : Specificity of a Bglucan receptor on macrophhages from Atlantic salmon(Salmosalar L.).Deve-lopmental and Comparative Immunology 18 (5 ) : 397 408 .

- Finn, J. P., and N. O. Nielson (1971): The inflammatory response of rainbow trout . J. Fish Biol., 3 : 463 - 478 .

- Fujiki, K.; H. Matsuyama, and T. Yano (1993): Effect of hotwater extracts from marine algae on resistance of carp and yellowtail against bacterial infections.Science Bulletin of the Fac.of Agri.,Univ.of kyushu, (47) : 137 - 141.

- Fujiki, K.; H. Matsuyama, and T. Yano (2000) : Protective effect of sodium alginates against bacterial infection in common carp, Cyprinus carpio L. Science Bulletin of the Faculty of Agriculture, Kyushu Univ-ersity, (58) : 349 - 355.

- Gado, M., and Iman Abd El-Aziz (2003): Studies on haemorrhagic septicemia associated with Hafnia alvei in some freshwater fishes. Kafr El-Sheikh Vet. Med. J. Vol. (1) No. 1: 395 - 417.

- Galina, J., and D. P. Anderson (1993): Glucan injection or bath exp-osure given alone or in combination with a bacterin enhance the non-specific defence mechanisms in rainbow trout (Oncorhynchus mykiss). Aqua 10026. Pp. 351 - 329.

- Gelev,I.;E.Gelev;A.G.Steigerwalt;G.P.Cartewr, and D. J. Brenner (1990): Identification of the bacterium associated with haemorrhagic septicaemia in rainbow trout as Hafnia alvei. Res. Microbiol. 141: 573 - 576. 
- Gibson,G.R. (1999): Dietary modulation of the human gut microflora using the prebiotics oligofructose and inulin . J. Nutr. (129) ; 1438s - 1441s.

- Hart, S.; A. B. Wrathmell, J. E. Harris, and T. H. Grayson (1988): Gut immunology in fish:A review.Dev.Comp.Immunol.,12 :453 - 480 .

- Jeney, G., and D. P. Anderson (1993): Enhanced immune response and protection in rainbow trout to Aeromonas salmonicida bacterin following prior immersion in immunostimulants . Fish Shellfish Imm-unol., 3 : 51 - 58.

- Lamers, C. H. J., and H. K. Parmentier (1985): The fate of intrape-ritoneally injected carbon particles in cyprinid fish cell. Tissue Res., 242 : 499 - 503 .

- Nicoletti,A.;G.Nicoletti;G.Palmieri;P.Mattaboni, and R. Germogli (1992): Preliminary Evaluation of Immunoadjuvant Activity of an Orally Administered Glucan Extracted from Candida albicans. Arznim-Forsch. / Drug Res. 42 (II) . Nr. 10.

- Nikl,L.; L. J. Albright,and T.P.T.Evelyn (1991): Influence of seven immunostimulants on the immune response of Coho salmon to Aero-monas salmonicida. Dis. Aquat. Org., 12: 7 - 12.

- L.; T. P. T. Evelyn, and L. J. Albright (1993): Trials with an orally and immersion-administrated B-1.3 glucan as an immunoproph-ylactic against Aeromonas salmonicida in Juvenile chinook salmon. Oncorhynchus tshawytscha.Diseases of Aquatic Orgaisms, 17:191-196.

- Onarheim, A. M. (1992 ): Now a yeast extract to fortify fish. Fish Farmer, 15 (4) : 45 (July / August).

- Raa,J.;G. Roerstad; R. Engstad, and B. Robertsen (1992) : The use of immunostimulants to increase resistance of aquatic organisms to microbial infections. In : M. Shariff, R. P. Subasinghe and J. R. Arthur (Editors), Diseases in Asian Aquaculture. I.Proceedings of the First Symposium on Diseases in Asian Aquaculture. 26 - 29 Nov. 1990. Manila, Philippines, Pp. 39 - 50. 
- Raa, J. (1996): The use of immunostimulatory Substances in Fish and Shellfish Farming. Reviews in Fisheries Science, 4 (3) : 229 288.

- Raa, J. (2000): The use of immune-stimulants in fish and shellfish feeds In :Cruz-Suarcz, L.E., Ricquc-Maric, D., Tapia-Salazar, M., Olvcra-Novo, M. A. y Civcra-Cerecedo, R., (Eds.). Avances en Nutricion Acuicola V. Memorias del V Simposium Internacional de Nutricion Acuicola, 19 - 22 Noviembre, 2000. Merida, Yucatan, Mexico.

- Robertson, B.; G. Rostad; R. Engstad, and J. Raa (1990): Enhancement of non-specific disease resistance in Atlantic salmon, Salmo salar L., by a glucan from Saccharomyces cerevisiae cell walls . J. Fish Dis., 13 : 391- 400.

- Rodriguez, L. A.; C. S. Gallardo; F. Acosta; T. P. Nieto; B. Acosta, and F.Real(1998) : Hafnia alvei as an opportunistic pathogen causing mortality in brown trout, Salmo trutta L. J. Fish Dis., $21: 365$ - 370 .

- Rombout, J. W. M.; H. E. Bot, and J. J. Taverne-Thiele (1989): Immunologic importance of the second gut segment of carp. II. Chara-cterization of mucosal leucocytes. J. Fish Biol., 35 : 167 178.

- Rombout, J. W. M.; J. J. Taverne-Thiele, and M. I.Villena(1993): The gut-associated lymphoid tissue(GALT)of carp (Cyprinus carpio L.): An immunocytochemical analysis. Dev. Comp. Immunol., 17 : 55 - 66.

- Ruangpan L.; T.Ritao, and H. Yasida (1986): Protective efficacy of Aeromonas hydrophila vaccine in Nile Tilapia. Vet. Immunal Pathol, $12: 345$ - 350 .

- Sanders,J. E., and J. L.Fryer(1988): Bacteria of fish. In: Methods in Aquatic Bacteriology (Ed.by B.Austin)115-143. John Wiley and Sons Ltd, Chichester.

- Song,Y. L., and Y.T.Hsieh(1994): Immunostimulation of tiger shrimp (Penaeus monodon) hemocytes for generation of 
microbicidal substa-nces : analysis of reactive oxygen species. Development and Compar-ative Immunology, 18 (3) : 201- 209.

- Song, Y. L.; J. J. Liu; L. C. Chan, and H. H. Sung (1997): Glucan induced diseases resistance in tiger shrimp (Penaeus monodon). In : Gudding, R., Lillehaug, A., Midtlyng, P. J., Brown, F.,Eds. Fish Vacc-inology. Pp. 413 - 421.

- Sövényi,J.F., and R. Kusuda (1987): Kinetics of in vitro phagocytosis by cells from hand-kidney of common carp, Cyprinus carpio. Fish Pathol., $22: 83$ - 92.

- Sung, H. H.; G. H. Kou, and Y. L. Song (1994): Vibriosis resistance induced by glucan treatment in tiger shrimp (Penaeus monodon). Fish Pathology, 29 (1) : 11 - 17.

- Sung, H. H.; Y. L. Yang, and Y. L. Song (1996): Enhancement of microbicidal activity in the tiger shrimp(Penaeus monodon) via immu-nstimulation . Journal of Crustacean Biology 16 (2) : 278 284.

- Sung, H. H.; H. J. Chang; C. H. Her; J. C. Chang, and Y. L. Song (1998): Phenoloxidase activity of hemocytes derived from Penaeus monodon and Macrobrachium rosenberghii.J. of Invertbrate Pathology, 71: 26 - 33.

- Supamattaya, P. (1998): The effect of MacroGard ${ }^{\circledR}$ on growth perfo-rmance and health condition of black tiger shrimp. Scientific repot, Princ of Songkhla University.

- Tashima C.; S. Kudo; Y. Ohtani, and A. Saito (1992): Kidney path-ology from the bacterium Hafnia alvei. Experimental evidence. Trans-actions of the American Fisheries Society (121), $599-607$.

- Thompson, K. D.; A. Cachos, and V. Inglis (1993a): Immunomodu-lating effects of glucans in the presence of oxytetracycline in rainbow trout, Oncorhynchus mykiss, Pp.31. Second Symposium on Diseases in Asian Aquaculture, Phuket, Thailand. 
- Thompson, A.; A. White; T. C. Fletcher; D. F. Houlihan, and C. J. Secombes $(1993$ b): The effect of stress on the immune response of Atlantic salmon(Salmo salar L.)Fed diets containing different amounts of vitamin C. Aquaculture, $114: 1$ - 18.

- Van Ginkel,F.W.;W.B.Van Muiswinkel; B. Merchant;E. F.Lizzio ; O. W.Dixon, and D. P. Anderson (1985): Temperature comparisons for antibody production in vitro by plaque froming cells from trout, Salmo gairdneri Richardson, and mice. J. Fish Biol., 27 : 265 - 272.

- Verlhac,V.;A.Obach; J.Gabaudan;W. Schuep,and R. Hole (1998): Immunomodulation of dietary vitamin $C$ and glucan in rainbow trout (Onchorhynchus my kiss). Fish and Shellfish Immunology, 8:409- 424.

- Warr,G.W., and N.Cohen (1991): Phylogenesis of immune functions. CRC Press, Boca Raton, FL, Pp. 326.

- Yano, T.; R. E. P. Mangindaan, and H. Matsuyama (1989): Enhan-cement of the resistance of carp Cyprinus carpio to experimental Edw-ardsiella tarda infection by some beta 1 - 3 glucans. Nippon Suisan Gakkaishi, 55 : 1815 - 1819.

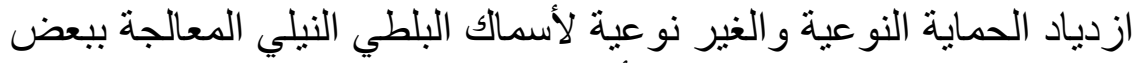

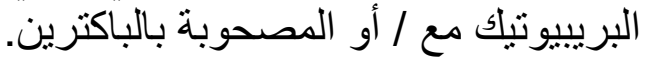

$$
\begin{aligned}
& \text { د / محمد سعيد جادو** و ــ / عزة القطاوي } \\
& \text { كلية الطب البيطري - بكفر الثيخ - جامعة طنطا } \\
& \text { *قتم الدواجن والأسماك. * * قسم الفسيولوجيا والكيمياء الحيوية. }
\end{aligned}
$$

تم إجراء العدوى الاصطناعية لأسماك البلطي النيلي ببكتريا الهافنيا ألفي،المسببة للتسمم الدموي

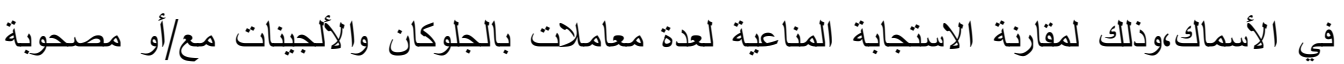
بلقاح الباكترين المضاد للهافنيا ألفي. 
لوحظ ارتفاع المناعة غير النوعية في أسماك البلطي النيلي المغمورة في محاليل من الجلوكان

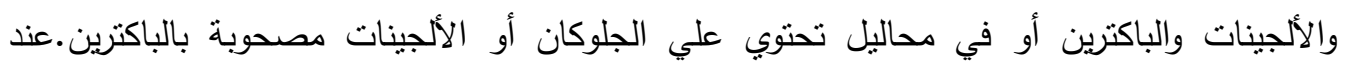
فحص عينات دم الأسماك في عدة أوقات مختلفة ، أظهرت الدراسة ارتفاع في نثاط الخئ الخلايا المحبية المتعادلة (نيتروفيل) من خلال مقدرة هذه الخلايا علي الالنصاق بالزجاج ، وكذا قدرتها علي إنتاج

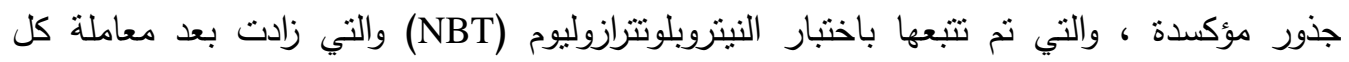
المجموعات في خلال 48 ساعة.

إن عدد الخلايا الملتصقة،من دم الأسماك المعاملة بالألجينات والجلوكان مع/أو مصحوباً بالباكترين بطريقة الغمر ،مرتفعاً ارتفاعا ملحوظاً ذو دلالة،عند مقارنته عند بداية التجربة أو عند مقارنته بالمجموعات الضابطة.

إن زيادة الخلايا الملتهمة ، والتي تم تتبعه بواسطة زيادة امتصاص كريات الدم الحمراء للأغنام لمادة الجلوترالد هيد،أكدت هذه الدينامبكية. أصبح من الواضح أن الأسماك المعاملة بالألجينات والجلوكان مصحوباً بالباكترين،أظهرت ديناميكية ملحوظة لزيادة المناعة الغير النوعية والنوعية. إن الألجينات والجلوكان من المنشطات المناعية الواعدة، حيث أنهما يمكن أن يلعبا دوراً

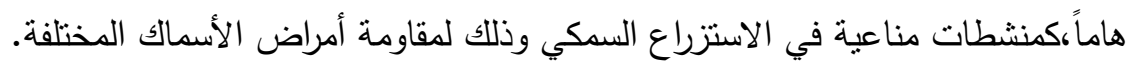

